(c) American Dairy Science Association, 2005.

\title{
Milk Quality and Automatic Milking: Fat Globule Size, Natural Creaming, and Lipolysis*
}

\author{
F. Abeni, ${ }^{1}$ L. Degano, ${ }^{2}$ F. Calza, ${ }^{1}$ R. Giangiacomo, ${ }^{2}$ and G. Pirlo ${ }^{1}$ \\ ${ }^{1}$ Consiglio per la Ricerca e Sperimentazione in Agricoltura, Istituto Sperimentale per la Zootecnia, \\ Sezione Operativa di Cremona, I-26100 Cremona, Italy \\ ${ }^{2}$ Consiglio per la Ricerca e Sperimentazione in Agricoltura, Istituto Sperimentale Lattiero Caseario, \\ I-26900 Lodi, Italy
}

\begin{abstract}
Thirty-eight Italian Friesian first-lactation cows were allocated to 2 groups to evaluate the effect of 1) an automatic milking system (AMS) vs. milking in a milking parlor (MP) on milk fat characteristics; and 2) milking interval ( $\leq 480,481$ to 600,601 to 720 , and $>720$ $\mathrm{min}$ ) on the same variables. Milk fat was analyzed for content ( $\% \mathrm{vol} / \mathrm{vol})$, natural creaming ( $\%$ of fat), and free fatty acids (FFA, mEq/100 $\mathrm{g}$ of fat). Distribution of milk fat globule size was evaluated to calculate average fat globule diameter $\left(\mathrm{d}_{1}\right)$, volume-surface average diameter $\left(\mathrm{d}_{32}\right)$, specific globule surface area, and mean interglobular distance. Milk yield was recorded to calculate hourly milk and milk fat yield. Milking system had no effect on milk yield, milk fat content, and hourly milk fat yield. Milk from AMS had less natural creaming and more FFA content than milk from MP. Fat globule size, globular surface area, and interglobular distance were not affected by milking system per se. Afternoon MP milkings had more fat content and hourly milk fat yield than AMS milkings when milking interval was $>480$ min. Milk fat FFA content was greater in AMS milkings when milking interval was $\leq 480$ min than in milkings from MP and from AMS when milking interval was $>600$ min. Milking interval did not affect fat globule size, expressed as $d_{32}$. Results from this experiment indicate a limited effect of AMS per se on milk fat quality; a more important factor seems to be the increase in milking frequency, generally associated with AMS.
\end{abstract} (Key words: automatic milking, dairy cow, fat globule, lipolysis)

Abbreviation key: AMS = automatic milking system, $\mathbf{d}_{\mathbf{1}}=$ average fat globule diameter, $\mathbf{d}_{\mathbf{3 2}}=$ volume-surface average fat globule diameter, $\mathbf{M P}=$ milking parlor .

Received December 17, 2004.

Accepted June 23, 2005.

Corresponding author: F. Abeni; e-mail: fabio.abeni@isz.it.

*This research was funded by a grant from the Italian Ministry of Agriculture and Forestry Policies ("Total automation of dairy barn").

\section{INTRODUCTION}

Automatic milking systems (AMS) offer a method for relieving the dairy producer from the labor-intensive routine of a traditional milking parlor (MP). Some major advantages are generally emphasized: reduced labor demand and a better social life for dairy producers; improved animal health and welfare; and increased milk yields (Lind et al., 2000). On the other hand, at least 2 disadvantages exist. Automatic milking systems require a large initial investment (Wauters and Mathijs, 2004) and could negatively affect some milk quality features, including total bacterial plate count, free fatty acids, freezing point, and perhaps, protein content (Klungel et al., 2000).

Each milk quality feature plays a different role when final milk destination is taken into account. When milk fat quality is examined, lipolytic damage may be of major concern to the fluid milk market. Milk fat lipolysis is the hydrolysis of fatty acids from fat globule triglycerides. Spontaneous lipolysis in fresh, high quality bovine milk is caused mainly by the activity of the native milk lipase, which is characterized as a lipoprotein lipase (EC 3.1.1.34; Santos et al., 2003). An increase in lipolysis in cold, stored milk is due to the action of milk lipoprotein lipase, which can be stimulated (induced lipolysis) by agitation, foaming, or temperature changes. The AMS leads to more milk FFA content than does MP (de Koning et al., 2004). Recently, Slaghuis et al. (2004) reported that milking frequencies seemed to be of more importance than technical traits of the AMS in determining milk FFA content, because FFA content was comparable for farms milking thrice daily in an MP and for those using an AMS. Increased milking frequency increased the activity of acetyl-coenzyme A carboxylase and fatty acid synthetase in goat mammary tissue (Travers and Barber, 1993), leading to an increase in de novo synthesis of short-chain fatty acids. Considering the general preference of milk lipase for triglycerides containing short-chain fatty acids over triglycerides containing long-chain fatty acids, Klei et al. (1997) suggested that the greater lipolysis in milk from thrice-daily milking compared with that of milk from 
twice-daily milking could be due to an increase in shortchain fatty acids in fat from the higher milking frequency. From this hypothesis, it is possible to suppose that milk fat globules could be richer in short-chain fatty acids in cows milked more frequently by an AMS.

In the traditional Italian dairy industry, milk is processed for typical products such as long-ripening cheeses (e.g., Grana Padano and Parmigiano Reggiano). The cheese-making processes involve different traditional stages that give specific features to the final product quality. Natural creaming is the traditional way to achieve the 2 main results that affect the quality of milk that reaches the kier; namely, a significant reduction in spore-forming bacteria, which could determine cheese loss during the ripening stage through the late blowing defect, and a standardization of milk fat-to-casein ratio, which is relevant for flavor development during the ripening stage (Bottazzi et al., 1995). Natural creaming is directly related to fat globule size, according to Stokes' law (Walstra, 1994).

Recent studies are available on milk fat globule size (Michalski et al., 2002, 2003), suggesting growing interest, from a technological point of view, about this topic. Therefore, the effect of a basic management factor such as milking system should be considered. Small fat globules having diameter $\leq 1 \mu \mathrm{m}$ represent $80 \%$ of the total number of globules, but only a small part of the total weight (Jensen et al., 1991). Fat globules of approximately $4 \mu \mathrm{m}$ represent $90 \%$ of the fat, but only 10 to $30 \%$ of globular numbers (Jensen et al., 1991). Larger globules having diameters between 8 and $12 \mu \mathrm{m}$ represent less than $1 \%$ of globular numbers, but contain 2 to $3 \%$ of the fat (Jensen et al., 1991). Skim milk, in which milk fat is composed of small globules, contains proportionally less $\mathrm{C}_{4: 0}$ to $\mathrm{C}_{10: 0}$ than cream, whereas milk fat is composed of larger globules (Jensen et al., 1991). Most biochemical evidence favors the interpretation that the major mechanism for secretion of milk lipid globules involves envelopment of droplets directly in plasma membrane (Jensen et al., 1991). Average diameter of fat globules $\left(\mathbf{d}_{1}\right)$ is not always representative of the size distribution. Therefore, it has become common to use the volume-surface average diameter $\left(\mathbf{d}_{32}\right)$, as suggested by Walstra (1994).

Few data are available on the effect of milking frequency or milking interval on milk fat variables. Klei et al. (1997) reported more milk fat yield, but also more FFA content in milk when cows were milked thrice rather than twice daily. Increase in FFA content, due to the reduced milking interval, was confirmed by Klungel et al. (2000), who also provided evidence that when milking occurred with an AMS, the increase was greater than that in milk from a third daily milking in an MP. Recently, Hamann et al. (2004) observed an increase in fat and FFA content as milking interval was reduced. This agrees with findings from SvennerstenSjaunja et al. (2004), who reported larger globules and more FFA content in milk after more frequent milkings ( 6 vs. 2 times daily). No results are available about the effect of milking interval on natural creaming.

The objectives of this study were to 1) determine the effects of the milking system on milk fat globule size, natural creaming, and lipolysis; 2) highlight interactions between milking system and sampling period of the year (seasonal pattern); and 3) discern whether some changes might be related to the different milking interval per se rather than to the milking system technology.

\section{MATERIALS AND METHODS}

\section{General}

This experiment was designed to compare the quality of milk obtained from 2 different milking systems. The traditional MP was a double-8 herringbone (DeLaval, Tumba, Sweden) and the AMS was a single box system (DeLaval VMS, DeLaval). The experiment was conducted from February to November 2003, with 6 sampling times: February 26-27, April 14-15, May 28-29, July 21-22, September 17-18, and November 3-4. A total of 38 Italian Friesian first-lactation cows that calved during all seasons represented by the sampling periods were allocated to the 2 milking systems based on calving date, average breeding value, age at first calving, and body condition. At the beginning of lactation, the cows were introduced into 2 similar herds, each composed of 50 cows. The 2 herds were also comparable in average milk yield and parity.

Both groups were housed in the same free-stall barn. At one end of the barn was located the traditional MP, and at the other end, the herd was milked with an AMS. Cows in the MP group were milked twice daily, whereas for cows in AMS group, the system was set to allow milking to occur at least $5 \mathrm{~h}$ after a previous milking, without regard to stage of lactation or yield. Cows in AMS that tried to reach the milking unit before the planned period were redirected to a feeding lane by a preselection gate.

Both groups were fed the same TMR once daily (at $0800 \mathrm{~h}$ ). Cows in AMS were offered $1 \mathrm{~kg} / \mathrm{d}$ of concentrate per $10 \mathrm{~kg}$ of daily milk yield in the milking stall. The concentrate had an average composition similar to that of the TMR. Cows in MP received an additional 0.5 to $1.5 \mathrm{~kg}$ of a concentrate to achieve a balance in average energy and protein intake between groups. 


\section{Sampling}

Milk samples were obtained during 6 periods, to represent various stages of lactation of each cow. At the end of the trial, however, samples from the first period (February 26 and 27) were not considered because of problems in milk fat analyses. Milk from MP was obtained from 2 consecutive milkings (1630 and $0530 \mathrm{~h}$ ) and each sample was analyzed. Milk from AMS was obtained at each voluntary milking during $48 \mathrm{~h}$, using an automatic sampler, which collected $50 \mathrm{~mL}$ of milk representative of the whole milking. Immediately after each collection, samples were cooled to $4^{\circ} \mathrm{C}$ and shipped to the laboratory to be analyzed within $6 \mathrm{~h}$.

\section{Laboratory Analyses}

Milk samples were analyzed for fat content using the Gerber method (International Dairy Federation, 1981) and data were expressed as volume/volume percentage. Milk yield per hour was calculated for each milking from the ratio between actual milk yield at that milking and the milking interval from the previous milking. Milk fat yield per hour was calculated from milk yield per hour and fat content of the sample. Natural creaming was determined according to Speroni and Bertoni (1984). Briefly, milk (14 mL) was placed into plastic tubes for $3 \mathrm{~h}$ in flowing water $\left(15^{\circ} \mathrm{C}\right)$. Fat at the surface was removed by aspiration, and then $2 \mathrm{~mL}$ of milk was aspirated from the bottom of the tube using a syringe and analyzed for milk fat content. Natural creaming was calculated as follows:

$$
\% \text { natural creaming }=(\mathrm{MF} 1-\mathrm{MF} 2) / \mathrm{MF} 1 \times 100
$$

where MF1 = milk fat content before natural creaming and MF2 = milk fat content after natural creaming. Lipolysis was determined according to Shipe et al. (1980), and data were expressed as milliequivalents of free fatty acids per 100 grams of fat.

Distribution of milk fat globule size was evaluated using a computerized inspection system for particle size analysis and dynamic shape characterization, employing laser and video technologies, respectively (CIS100, Ankersmid B.V., Oosterhout, The Netherlands), as previously described (Degano et al., 2004). According to Walstra (1994), the volume-surface average diameter $\mathrm{d}_{32}$ was chosen to numerically summarize fat globule distribution better than average fat globule diameter $\mathrm{d}_{1}$.

From data on fat content and globular size, 2 variables were calculated. The specific globule surface area in $100 \mathrm{~mL}$ of milk was calculated as follows (Walstra, 1994):
Globule surface area $=6 \varphi / d_{32}$

where $\varphi=$ volume fraction of fat (\% vol $/ \mathrm{vol})$. The mean interglobular distance was calculated as follows (Walstra, 1969):

$$
x=0.225 \mathrm{~d}_{32}[(74 / \varphi)-1]
$$

where $x$ was expressed in $\mu \mathrm{m}$.

\section{Statistical Analyses}

Due to the variable milking intervals in AMS, milk yields were treated as production rate per hour, as a quotient of the actual milk yield and the corresponding milking interval (Weiss et al., 2004). Stage of lactation for each cow was assessed at $\leq 90,91$ to 180,181 to 270 , and $>270$ DIM. To evaluate the effect of milking interval, 6 classes were created: 4 classes for the AMS, in which each milking was classified according to the time elapsed since the previous one $(\leq 480,481$ to 600 , 601 to 720 , and $>720 \mathrm{~min}$ ) and 2 classes for the MP (afternoon milking interval $=11 \mathrm{~h}$ and morning milking interval $=13 \mathrm{~h}$ ).

Normal distribution of milk fat variables was tested with the Shapiro-Wilk test before further analysis, using the PROC UNIVARIATE of the SAS statistical package (SAS Inst., Inc., Cary, NC). Time-sequence data were submitted to the ANOVA and analyzed as a split-plot in a completely randomized design with MIXED models using the SAS statistical package. The model considered for the evaluation of milking system effects included milking system (MP vs. AMS), stage of lactation ( $\leq 90,91$ to 180,181 to 270 , and $>270 \mathrm{DIM}$ ), sampling period (April 14-15, May 28-29, July 21-22, September 17-18, and November 3-4) to account for season, the interaction between milking system and stage of lactation, the interaction between milking system and sampling period, and the random effect of the individual cow.

The MIXED model considered for the evaluation of milking interval effect included milking interval $(\leq 480$, 481 to 600,601 to 720 , and $>720 \mathrm{~min}$ ), stage of lactation ( $\leq 90,91$ to 180,181 to 270 , and $>270$ DIM), sampling period (April 14-15, May 28-29, July 21-22, September 17-18, and November 3-4), the interaction between milking interval and stage of lactation, the interaction between milking interval and sampling period, and the random effect of the individual cow.

Main effects and their interactions were reported when a significant $F$-test was detected $(P \leq 0.05)$, unless otherwise stated; interactions were evaluated using the PDIFF option of the SAS software. Differences among 
Table 1. Results from ANOVA of the milk fat variables according to milking system and significance of the factors for each selected model.

\begin{tabular}{|c|c|c|c|c|c|c|c|c|c|}
\hline \multirow[b]{2}{*}{ Item } & \multicolumn{4}{|c|}{ Milking system } & & & & & \\
\hline & Mean & $\mathrm{SE}$ & Mean & $\mathrm{SE}$ & $\mathrm{MS}^{1}$ & $\mathrm{SOL}^{2}$ & $\mathrm{MS} \times \mathrm{SOL}$ & Period & MS $\times$ Period \\
\hline Milk yield, kg/h & 1.12 & 0.07 & 1.03 & 0.08 & NS & NS & 0.011 & $<0.0001$ & NS \\
\hline Fat content, \% vol/vol & 3.7 & 0.16 & 3.70 & 0.17 & NS & NS & NS & $<0.0001$ & $<0.0001$ \\
\hline Fat yield, $\mathrm{g} / \mathrm{h}$ & 37.8 & 2.33 & 34.0 & 2.30 & NS & $\mathrm{NS}$ & $\mathrm{NS}$ & $<0.0001$ & NS \\
\hline Natural creaming, $\%$ of fat & 44.5 & 2.62 & 37.9 & 2.56 & 0.080 & 0.003 & NS & $<0.0001$ & 0.001 \\
\hline Globular surface area, $\mathrm{m}^{2} / \mathrm{dL}$ milk & 5.23 & 0.20 & 5.10 & 0.20 & NS & NS & NS & $<0.0001$ & 0.003 \\
\hline Interglobular distance, $\mu \mathrm{m}$ & 21.1 & 1.10 & 22.3 & 1.06 & NS & NS & NS & $<0.0001$ & 0.070 \\
\hline
\end{tabular}

means are reported when $P \leq 0.05$, unless otherwise stated.

A correlation analysis, which estimated the linear relationship within milk fat variables and between milk fat variables and cow and milking data, was performed for each sampling period using the CORR procedure of SAS, and Pearson's correlation coefficients were calculated.

\section{RESULTS}

\section{Effect of Milking System and its Interaction with Stage of Lactation and Sampling Period}

Results from the ANOVA including the effect of milking system, stage of lactation, sampling period, and their interactions are reported in Table 1.

Milking system had no effect on milk yield per hour (Table 1). A significant interaction was detected between milking system and stage of lactation at 91 to 180 DIM; cows milked in the MP had more $(P<0.05)$ milk yield per hour than those milked in the AMS (1.19 vs. $0.86 \mathrm{~kg}$, respectively). Season affected milk yield per hour, but no interaction was evident between season and milking system.

Fat content was not affected by milking system, stage of lactation, or by their interaction (Table 1). An interaction $(P<0.0001)$ emerged between milking system and sampling period (Table 1), with a trend for more $(P=$ 0.06) fat content in milk from AMS cows than from MP cows milk on September 17-18 (4.19 vs. $3.60 \%$ vol/ vol, respectively).

Sampling period affected $(P<0.0001)$ milk fat yield per hour (Table 1), whereas milking system, stage of lactation, and their interaction did not affect this variable. Milk fat yield per hour was less $(P<0.05)$ at midsummer samplings $(30.6 \mathrm{~g} / \mathrm{h}$ on July $21-22)$ than at other periods (39.7, 37.5, 35.3, and $36.2 \mathrm{~g} / \mathrm{h}$ on April
14-15, May 28-29, September 17-18, and November $3-4$, respectively).

A trend $(P=0.08)$ was detected for more natural creaming in MP than in AMS milk (Table 1; Figure 1a and 1b). Stage of lactation influenced natural creaming, but no interaction was detected between milking system and stage of lactation. Sampling period also affected natural creaming, in addition to an interaction of sampling period with milking system $(P=0.001)$. As shown in Figure 1b, natural creaming values were greater $(P<0.05)$ in MP than in AMS milk on May 28 29 and November 3-4.

Milk fat lipolysis was affected by milking system, with more $(P<0.05)$ FFA in fat from AMS at each stage of lactation (Table 1; Figure 2a). Milk fat lipolysis was affected by the sampling period, and a significant interaction was observed between milking system and sampling period (Table 1; Figure 2b). In fact, milk samples from April and November had more $(P<0.05)$ FFA in AMS than in MP fat, whereas differences between milking system were not significant from May to September (Figure $2 \mathrm{~b}$ ). For MP milk, the greatest $(P<0.05)$ amount of FFA was recorded in July and for AMS milk, FFA content was less $(P<0.05)$ in September than during the other 4 sampling periods. Fat globule size, expressed as $\mathrm{d}_{32}$, was not affected by milking system (Table 1), but was affected by stage of lactation and a significant interaction between milking system and stage of lactation (Table 1; Figure 3a). For MP milk, $\mathrm{d}_{32}$ was greater $(P<0.05)$ during early lactation than during subsequent stages (Figure 3a), whereas for AMS milk, $\mathrm{d}_{32}$ was greater $(P<0.05)$ during earlier lactation than during subsequent stages. A difference $(P<0.05)$ was detected between the second, third, and fourth stages of lactation. During the second stage of lactation (91 to $180 \mathrm{DIM})$, fat globule size was greater $(P<0.05)$ in AMS than in MP milk. Sampling period affected fat 
a)

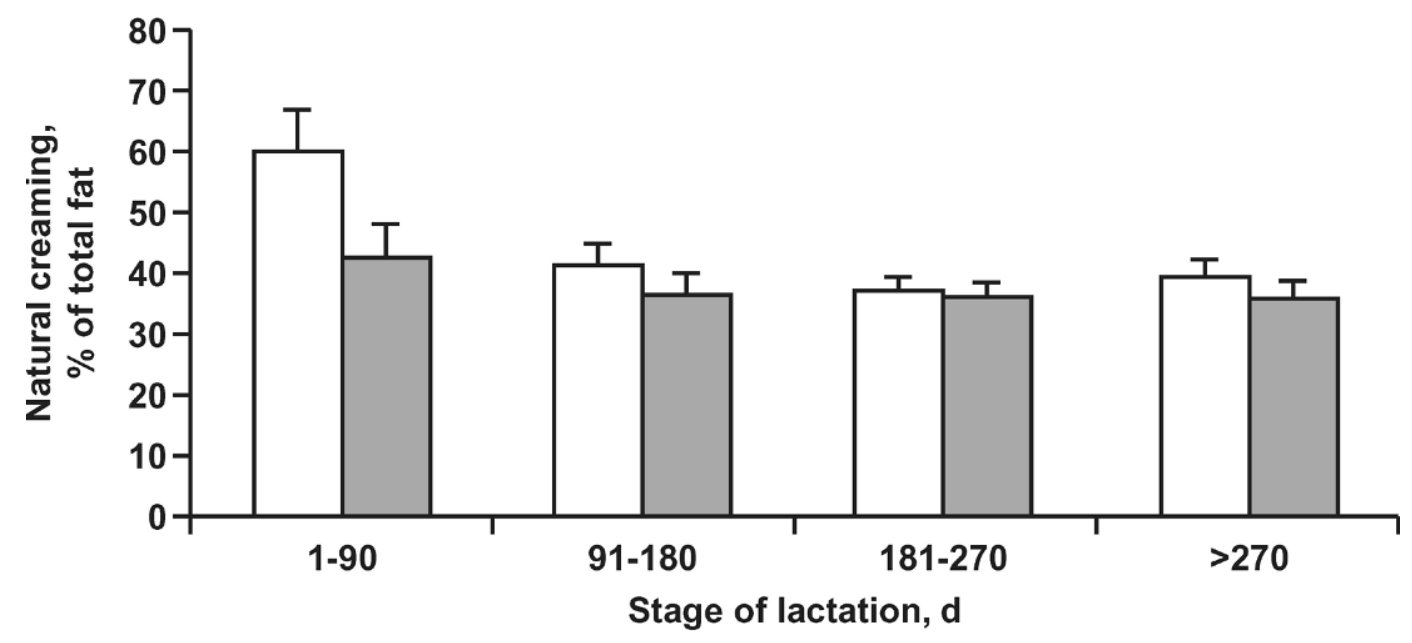

b)

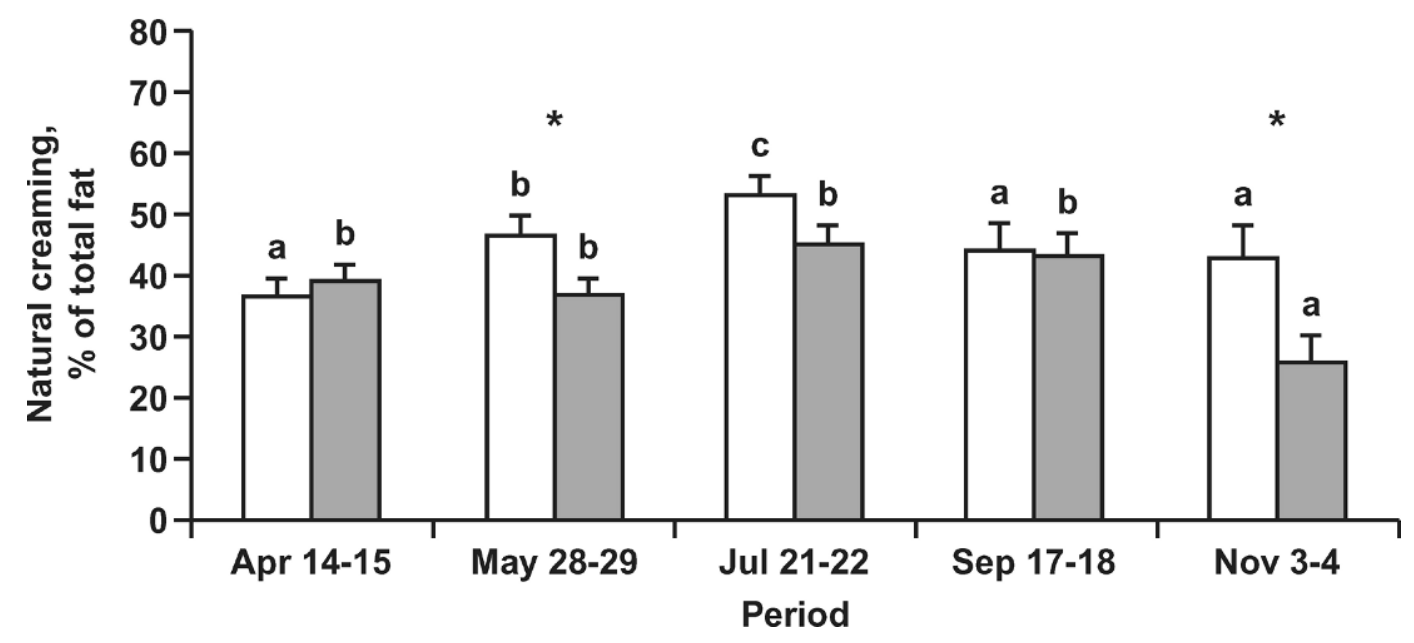

Figure 1. Natural creaming values (least square means \pm SEM; as a percentage of total fat) in milk obtained from first-lactation cows in a traditional milking parlor system (MP; open bars) or in an automatic milking system (AMS; hatched bars) according to a) stage of lactation, and b) sampling period. Bars within stage of lactation or season with an asterisk above differ for the reported $P$-value. Bars within milking system without a common letter differ $(P<0.05)$.

globule size (Table 1$)$ and an interaction $(P<0.05)$ was detected between milking system and sampling period, with a greater $d_{32}$ in AMS than in MP milk during the July sampling period. We observed a Pearson's correlation coefficient of $0.516(P<0.0001)$ between milk fat content and $\mathrm{d}_{1}$, indicating that an increase in milk fat content generally occurred through an increase in fat globule size. Globular surface area was not affected by milking system, stage of lactation, or their interaction (Table 1). Globular size was affected $(P<0.0001)$ by sampling period and an interaction $(P=0.003)$ between milking system and sampling period (Table 1). Interglobular distance was not affected by milking system, stage of lactation, or their interaction, but sampling period $(P<0.0001)$, and a trend $(P=0.07)$ for an interaction between milking system and sampling period was observed (Table 1).

\section{Effect of Milking Interval}

Milking interval did not affect milk yield per hour, but an interaction $(P<0.05)$ was detected between milking interval and stage of lactation (Table 2). When milking intervals were $>720$ min between 181 and 270 DIM and when milking intervals were $>600$ min after 270 DIM, less $(P<0.05)$ milk yield per hour was observed in AMS cows than in both milkings (afternoon and morning) for MP cows. 
a)

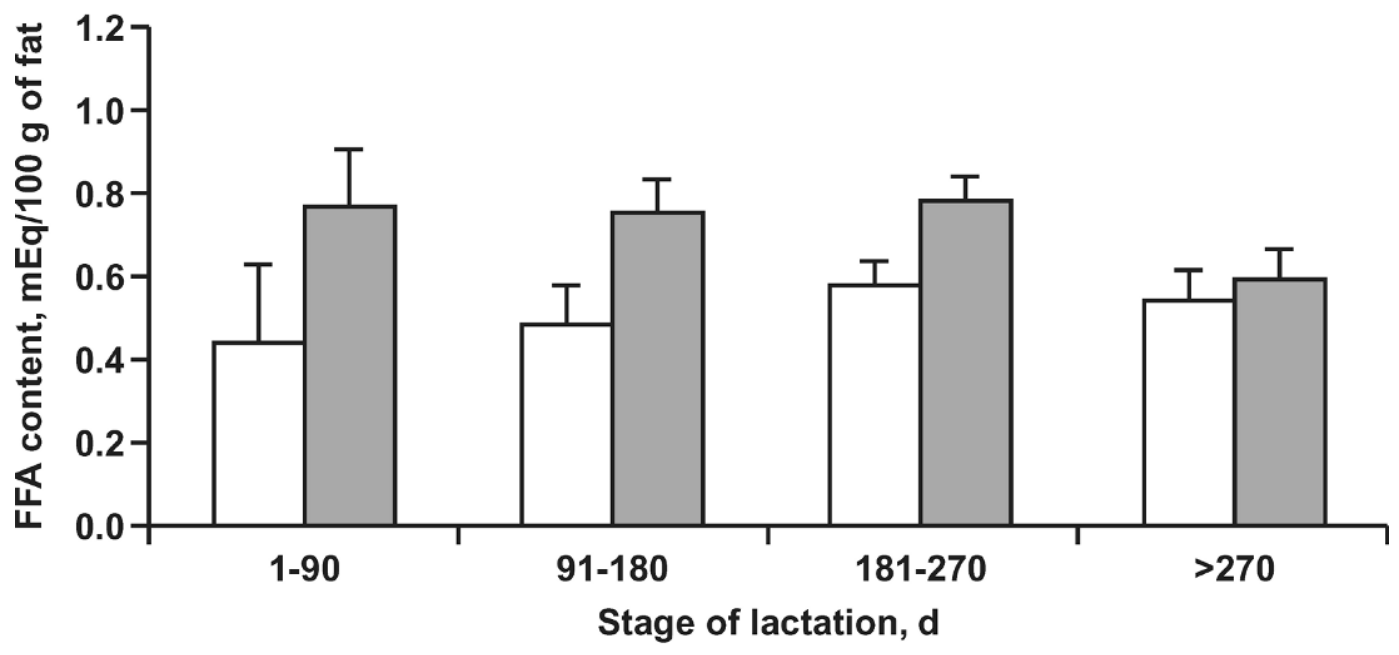

b)

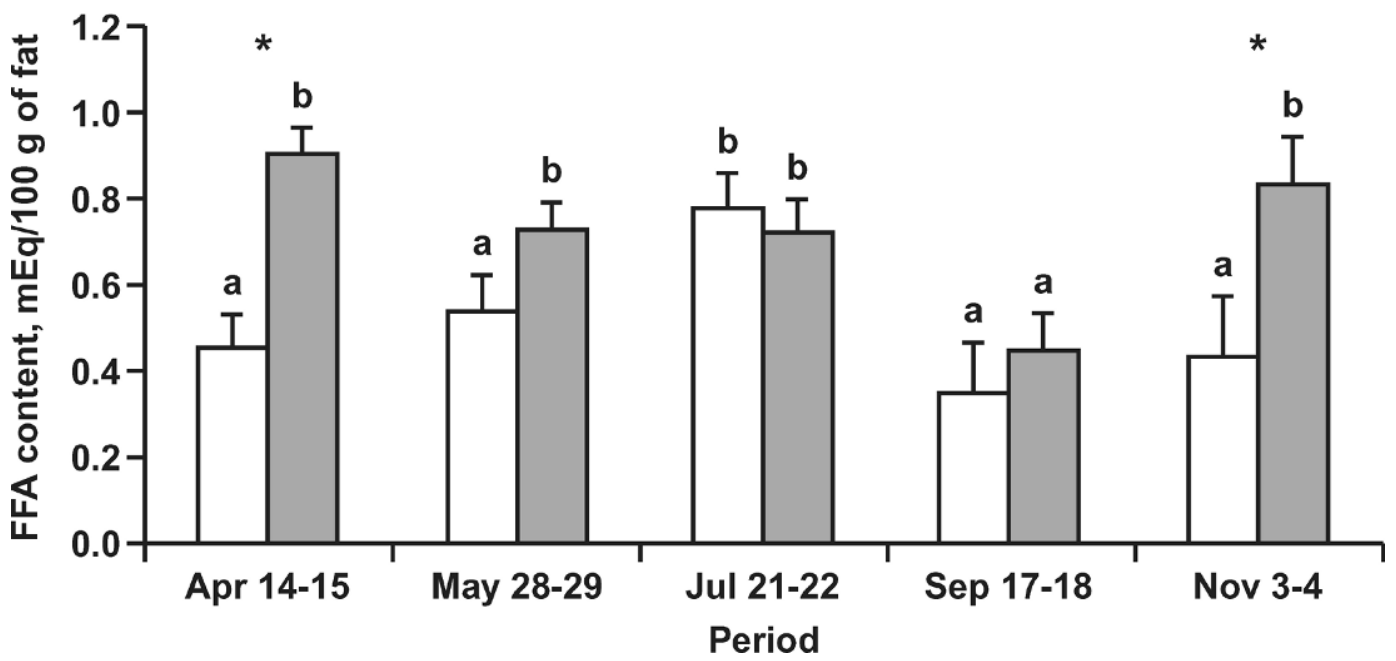

Figure 2. Free fatty acid content in milk fat (least square means $\pm S E M ; m E q / 100 \mathrm{~g}$ of fat) obtained from first-lactation cows in a traditional milking parlor system (MP; open bars) or in an automatic milking system (AMS; hatched bars) according to a) stage of lactation, and b) sampling period. Bars within stage of lactation or season with am asterisk above differ for the reported $P$-value. Bars within milking system without a common letter differ $(P<0.05)$.

No significant interactions were detected for the other variables considered, between milking interval and stage of lactation. Therefore, only milking interval effect is presented. Milking interval affected $(P=0.05)$ milk fat content (Table 3). The MP afternoon milk, which was characterized by an average milking interval of $11 \mathrm{~h}$, had more milk fat content than that obtained in the MP morning milk. Milk fat content also was greater $(P<0.05)$ in AMS milk when the milking interval was $>480 \mathrm{~min}$.

Milking interval affected $(P<0.05)$ hourly milk fat yield (Table 3 ). Afternoon milk obtained from MP cows had a greater $(P<0.05)$ hourly milk fat yield than that obtained from AMS cows with milking interval $>480$ min. Milking interval did not affect natural creaming (Table 3).

Milk fat FFA was affected $(P=0.005)$ by milking interval (Table 3$)$. The shorter milking intervals $(\leq 600$ min) for AMS cows resulted in greater $(P<0.05)$ FFA content than both milking intervals for MP cows. In addition, AMS milk in which milking intervals $\leq 480$ min contained higher $(P<0.05) \mathrm{FFA}$ content than did milk from AMS milkings when milking interval >-600 min (Table 3), whereas no differences were detected for MP milk. In our study, within AMS, we observed a positive correlation $(\mathrm{r}=0.158 ; P<0.01)$ between FFA 
a)

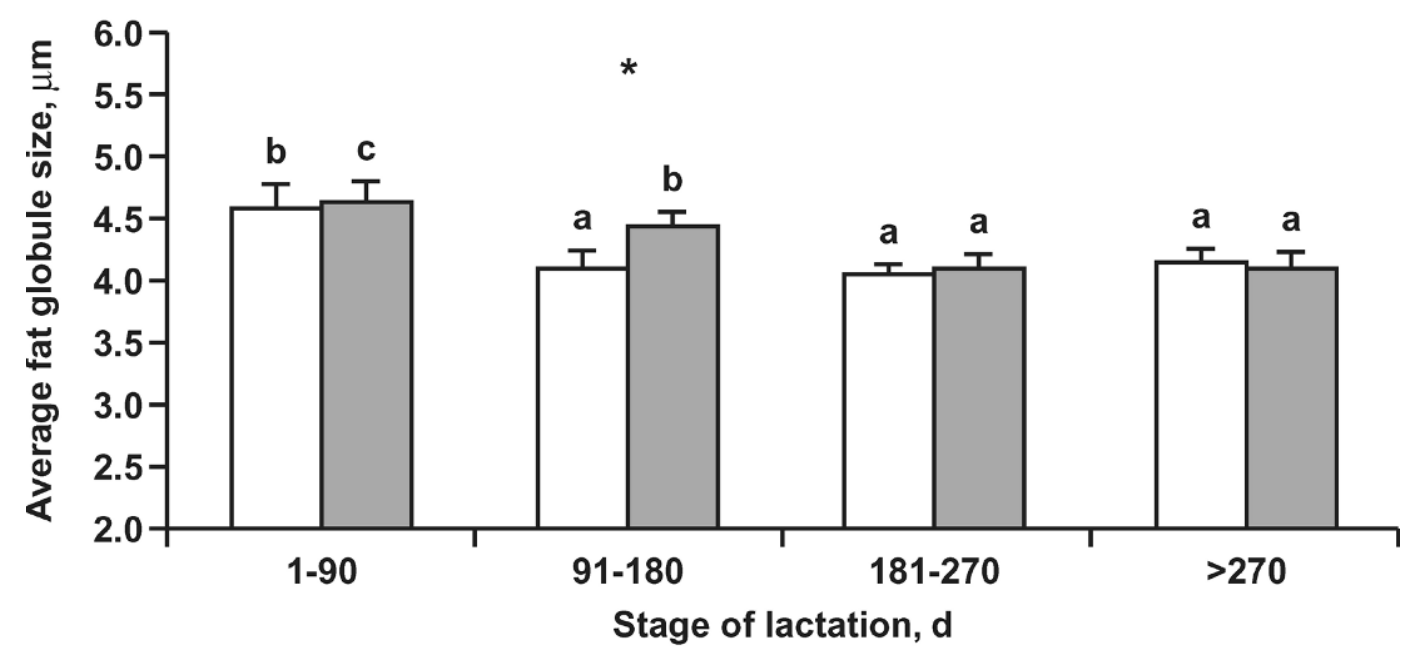

b)

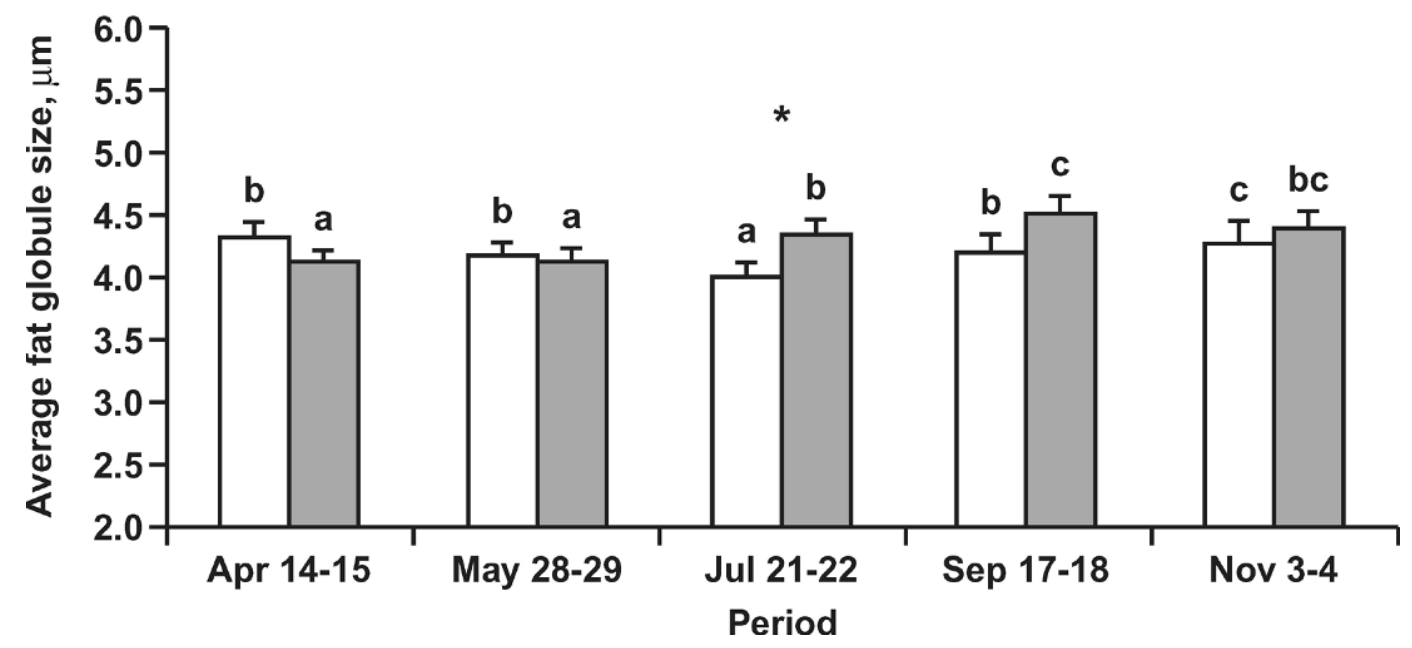

Figure 3. Average fat globule size $\left(d_{32}, \mu \mathrm{m}\right)$ of milk fat (least square means \pm SEM) obtained from first-lactation cows in traditional milking parlor system (MP; open bars) or in an automatic milking system (AMS; hatched bars) according to a) stage of lactation, and b) sampling period. Bars within stage of lactation or season with an asterisk above differ for the reported $P$-value. Bars within milking system without a common letter differ $(P<0.05)$.

Table 2. Results from ANOVA of the milk yield per hour $(\mathrm{kg} / \mathrm{h})$ within milking system according to milking interval class and stage of lactation.

\begin{tabular}{|c|c|c|c|c|c|c|}
\hline \multirow{2}{*}{$\begin{array}{l}\text { Stage of } \\
\text { lactation, } \\
\text { DIM }\end{array}$} & \multicolumn{4}{|c|}{ Milking intervals for automatic milking system, min } & \multicolumn{2}{|c|}{ Milking parlor } \\
\hline & $\leq 480$ & 481 to 600 & 601 to 720 & $>720$ & Afternoon & Morning \\
\hline$\leq 90$ & $1.08 \pm 0.15^{\mathrm{d}}$ & $1.06 \pm 0.16$ & $0.95 \pm 0.33$ & $1.36 \pm 0.32$ & $0.96 \pm 0.18$ & $0.97 \pm 0.18$ \\
\hline 91 to 180 & $0.86 \pm 0.11^{\mathrm{ac}}$ & $0.99 \pm 0.11^{\mathrm{ab}}$ & $1.05 \pm 0.15^{\mathrm{ab}}$ & $1.03 \pm 0.14^{\mathrm{ab}}$ & $1.15 \pm 0.10^{\mathrm{b}}$ & $1.23 \pm 0.10^{\mathrm{b}}$ \\
\hline 181 to 270 & $1.13 \pm 0.07^{\mathrm{bd}}$ & $1.10 \pm 0.08^{\mathrm{ab}}$ & $1.02 \pm 0.10^{\mathrm{ab}}$ & $0.88 \pm 0.10^{\mathrm{a}}$ & $1.13 \pm 0.06^{\mathrm{b}}$ & $1.19 \pm 0.06^{\mathrm{b}}$ \\
\hline$>270$ & $1.25 \pm 0.09^{\mathrm{bd}}$ & $1.11 \pm 0.10^{\mathrm{b}}$ & $0.89 \pm 0.13^{\mathrm{a}}$ & $0.86 \pm 0.13^{\mathrm{a}}$ & $1.17 \pm 0.08^{\mathrm{b}}$ & $1.19 \pm 0.08^{b}$ \\
\hline
\end{tabular}

${ }^{\mathrm{a}, \mathrm{b}}$ Least square means $\pm \mathrm{SE}$ having different superscript letters in the same row differ $(P<0.05)$.

${ }^{\mathrm{c}, \mathrm{d}}$ Least square means $\pm \mathrm{SE}$ having different superscript letters in the same column differ $(P<0.05)$. 
Table 3. Results from ANOVA (least square means \pm SE) of the milk fat features within milking system ${ }^{1}$ according to milking interval class.

\begin{tabular}{|c|c|c|c|c|c|c|}
\hline Item & \multicolumn{4}{|c|}{ Milking interval for AMS, min } & \multicolumn{2}{|c|}{ MP } \\
\hline Fat content, $\% \mathrm{vol} / \mathrm{vol}$ & $3.71 \pm 0.18^{\mathrm{ab}}$ & $3.36 \pm 0.19^{\mathrm{a}}$ & $3.18 \pm 0.28^{\mathrm{a}}$ & $3.20 \pm 0.26^{\mathrm{a}}$ & $3.98 \pm 0.18^{\mathrm{b}}$ & $3.46 \pm 0.17^{\mathrm{a}}$ \\
\hline Natural creaming, $\%$ of fat & $39.39 \pm 2.70$ & $39.29 \pm 2.74$ & $37.60 \pm 3.51$ & $37.84 \pm 3.45$ & $39.00 \pm 2.38$ & $44.84 \pm 2.36$ \\
\hline FFA, mEq/100 g of fat & $0.863 \pm 0.072^{\mathrm{c}}$ & $0.700 \pm 0.073^{\mathrm{bc}}$ & $0.501 \pm 0.122^{\mathrm{ab}}$ & $0.521 \pm 0.123^{\mathrm{ab}}$ & $0.528 \pm 0.080^{\mathrm{ab}}$ & $0.480 \pm 0.081^{\mathrm{a}}$ \\
\hline $\mathrm{d}_{32},{ }^{2} \mu \mathrm{m}$ & $4.353 \pm 0.105$ & $4.145 \pm 0.108$ & $4.194 \pm 0.158$ & $4.075 \pm 0.151$ & $4.244 \pm 0.102$ & $4.214 \pm 0.101$ \\
\hline $\begin{array}{l}\text { Globular surface area, } \\
\mathrm{m}^{2} / \mathrm{dL} \text { of milk }\end{array}$ & $5.074 \pm 0.234$ & $4.807 \pm 0.240$ & $4.530 \pm 0.362$ & $4.747 \pm 0.352$ & $5.584 \pm 0.239$ & $4.867 \pm 0.236$ \\
\hline
\end{tabular}

${ }^{a, b, c}$ Means having different superscript letters in the same row differ $(P<0.05)$.

${ }^{1} \mathrm{MP}=$ Milking parlor; AMS = automatic milking system.

${ }^{2} \mathrm{~d}_{32}=$ Volume-surface average diameter.

level and milk yield per hour, and negative correlations between FFA and fat content $(\mathrm{r}=-0.239 ; P<0.001)$ and between FFA and milk fat yield per hour $(\mathrm{r}=-0.208$; $P$ $<0.001$ ).

Fat globule size $\left(\mathrm{d}_{32}\right)$, globular surface area, and interglobular distance were not affected by milking interval (Table 3).

\section{DISCUSSION}

\section{Milk Yield per Hour, Milk Fat Content, and Milk Fat Yield per Hour}

The main results of our trial for these variables concerned differences obtained with different milking intervals, because the milking system per se did not seem to affect them (Table 1). The reduced milk yield per hour obtained during AMS milkings when milking interval $>720$ min during late lactation (Table 2) supported the suggestion that the secretion rate decreases with time (Ouweltjes, 1998), which was confirmed by studies in which cows were milked thrice daily (DePeters et al., 1985; Gisi et al., 1986; Klei et al., 1997).

Milk fat yield per hour tended to be greater when milking interval was shorter (Table 3). Milk fat yield per hour paralleled results for milk yield per hour. Milk fat and yield per hour confirm observations of DePeters et al. (1985) and Gisi et al. (1986) for first-lactation cows milked in an MP. They reported an increase in milk fat yield because of an increase in milk yield when milking frequency increased from twice to thrice daily. We are unaware of any reports with which we can compare the absolute values observed in our study. Milk fat secretion rate, however, tended to be enhanced in the AMS, with shorter milking intervals. One hypothesis may be linked to the observation that increased milking frequency enhanced the activity of acetyl-coenzyme A carboxylase and fatty acid synthetase in goat mammary tissue (Travers and Barber, 1993). Therefore, increased milking frequency may have increased fat synthesis. Greater milk fat yield per hour in cows milked in MP compared with those milked in AMS might be related to more evenly spaced milking intervals. Effects of regular milking intervals on milk yield and milk fat yield are well established (Ormiston et al., 1967). Further research on this issue is warranted.

\section{Natural Creaming and Milk Fat Globules}

Greater proportion of natural creaming during early lactation for cows milked in the MP confirms previous results (Piccioli Cappelli et al., 1990). The study of Piccioli Cappelli et al. (1990) indicated that larger longchain fatty acid content of milk fat occurs during early lactation stage when a greater proportion of lipid is derived from body fat mobilization rather than from de novo mammary synthesis. It is not known why the natural creaming was less in milk harvested by AMS compared with that harvested in the MP at each stage of lactation.

In May and November, natural creaming was less in AMS than in MP milk (Figure 1b). Trevisi et al. (1992) reported a rapid decline in natural creaming from summer to fall in a traditional MP. In their review, Calamari and Mariani (1998) reported a general agreement on the positive enhancing effect of warmer seasons on natural creaming, probably due to the relative increase in long-chain fatty acids (Ronchi et al., 1995). Differences between MP and AMS natural creaming in May and November are difficult to explain based on our results, considering the absence of differences in those sampling periods for $d_{32}$ (Figure $3 b$ ).

A lack of relationships among the values of natural creaming and the values of $\mathrm{d}_{32}$ and interglobular distance indicates that other factors play an important role in the creaming process. Further research with 
additional analyses on milk fat globule membrane and $\zeta$-potential (Michalski et al., 2002) may clarify differences in natural creaming.

\section{Milk Fat Lipolysis}

Milk obtained from cows milked in the AMS had greater milk fat FFA content than that obtained from cows in the MP, as recently confirmed by de Koning et al. (2004). The FFA content was greater in milk obtained from AMS milkings when milking interval was $\leq 480$ min than from AMS milkings when milking interval was $>600 \mathrm{~min}$. Our reduced milking interval effects on milk FFA content confirms earlier observations (Ahrné and Björck, 1985). Those authors also reported a difference between morning and afternoon milkings, which was not observed in our experiment. Recently, Slaghuis et al. (2004) reported that milking frequency seemed to be of greater importance when determining milk FFA content than the milking system per se, because FFA content in milk obtained from milk in which cows were milked thrice daily in an MP was comparable with milk obtained from cows milked in an AMS.

The interaction between milking system and season resulted in greater FFA content in milk fat from AMS during early spring and mid autumn. Reasons for this phenomenon are not obvious, but warrant further research.

Comparing the trends in Table 3 , it is evident that an increase in FFA content was found in milk harvested after shorter milking intervals, which was similarly characterized by a large $d_{32}$. Wiking et al. (2004) reported that milk having the largest milk fat globules was more unstable when subjected to movement and pumping, and was characterized by increased FFA content. However, in our study, milk was submitted to limited movement, because it was collected with a sampler just after milking before being transported in the milk lines. Svennersten-Sjaunja et al. (2004) also observed greater FFA content and larger fat globules in milk harvested from cows milked more than twice daily.

An unresolved question when evaluating factors affecting milk fat lipolysis concerns the relationships with DIM and stage of pregnancy. Ahrné and Björck (1985) reported a close relationship between milk FFA and DIM, but they did not seem to account for stage of pregnancy, probably resulting in a confounding of the 2 factors. Chazal and Chilliard (1986) more correctly suggested that pregnancy played a major role in the increase of milk FFA content observed during late lactation.

Another issue is the relationship of FFA content with milk yield per hour. Ahrné and Björck (1985) reported a positive correlation between milk yield and FFA con- tent, but caution must be exercised in comparing that work with our results because the earlier study did not consider the effective hourly rate of milk yield.

Considering the results from Santos et al. (2003) expressed on $2 \%$ standardized fat milk, we suppose that the values of FFA $(0.720 \mathrm{mEq} / 100 \mathrm{~g}$ of fat $)$ in milk obtained from the AMS are not large enough to alter practical usage of the milk. Our values were larger than those reported by Hamann et al. (2004), but comparable with those from Klei et al. (1997) with thrice daily milking and from Klungel et al. (2000) with AMS. Two hypotheses could be formulated to explain the high spontaneous lipolysis of milk fat after short milking intervals. The first, already suggested by Klei et al. (1997), is based on the observation that increased milking frequency increased the activity of acetyl-coenzyme A carboxylase and fatty acid synthetase in goat mammary tissue (Travers and Barber, 1993). These increased activities led to increased de novo synthesis of short-chain fatty acids (Jensen et al., 1991). A possible explanation of our results might be found in the combined effects of stage of lactation on acyl chain length and on milk lipoprotein lipase preferences for its cleaving action. During early lactation, the proportion of long-chain fatty acids is greater than that during late lactation, when short- and medium-chain fatty acids from mammary synthesis increase (Grummer, 1991). Palmquist et al. (1993) indicated that milk lipase has a preference to cleave fatty acids from the $s n-1$ and $s n$ 3 positions before that of the $s n-2$ position. In addition, milk lipase prefers a short-chain fatty acid to a longchain fatty acid at the $s n-1$ and $s n-3$ positions (Palmquist et al., 1993). These findings were confirmed by the study of Klei et al. (1997), in which it was shown that milk lipase prefers triglycerides containing shortchain fatty acids to triglycerides containing long-chain fatty acids. Therefore, increased milking frequency could be at the origin of milk triglycerides that are more susceptible to spontaneous lipolysis.

A second possible explanation, in our opinion, could be derived from the work of Cartier et al. (1990). They observed that inhibition of spontaneous lipolysis appeared when milk fractions contained component 3 of proteose-peptone. At present, we do not know whether this component is involved in the process; however, considering the effect of milking interval on proteolytic process, with reduced proteolysis reducing milking interval (Klei et al., 1997), it seems reasonable to suppose that an end product of proteolysis might be involved in the inhibition of lipolysis.

\section{CONCLUSIONS}

Our results confirmed a very limited (and not significant) effect of AMS, when compared with MP, on milk 
fat yield in first-lactation cows. Some milk fat features were affected. Natural creaming tended to be reduced by AMS. Content of FFA in milk fat increased with AMS because of an increased milking frequency. On the other hand, milk fat lipolysis was greater after shorter milking intervals, when fat globule size $\left(\mathrm{d}_{32}\right)$ tended (not significantly) to be greater.

Our findings suggest that AMS affects milk fat features mainly because of the increased milking frequency. Further applied research is warranted to show whether quality problems such FFA content may be reduced by different herd management. Further research is warranted in multiparous cows, because milk fat quality is greatly affected by body reserve mobilization in early lactation.

\section{ACKNOWLEDGMENTS}

This research was funded by the Finalized Project "Total automation of dairy barn" (Ministry of Agriculture and Forestry Policies, Italy). The authors acknowledge their colleagues (M. Capelletti, M. Speroni, and L. Migliorati) and workers (M. Dissegna and P. Re) at the Cremona Dairy Cow Section of the Animal Production Research Institute that made this research possible, with a special thanks to the chief of the farm staff, L. Brusa, for his assistance.

\section{REFERENCES}

Ahrné, L., and L. Björck. 1985. Lipolysis and the distribution of lipase activity in bovine milk in relation to stage of lactation and time of milking. J. Dairy Res. 52:55-64.

Bottazzi, V., B. Battistotti, and L. Bertozzi. 1995. La qualità del latte crudo per la produzione di formaggi duri a lunga stagionatura. Pages 289-308 in La certificazione dei prodotti alimentari: Il caso del latte. G. Piva and G. Enne, ed. Il Mulino, Bologna, Italy.

Calamari, L., and P. Mariani. 1998. Effects of the hot environment conditions on the main milk cheesemaking properties. Zoot. Nutr. Anim. 24:259-271.

Cartier, P., Y. Chilliard, and D. Paquet. 1990. Inhibiting and activating effects of skim milks and proteose-peptone fractions on spontaneous lipolysis and purified lipoprotein lipase activity in bovine milk. J. Dairy Sci. 73:1173-1177.

Chazal, M.-P., and Y. Chilliard. 1986. Effect of stage of lactation, stage of pregnancy, milk yield and herd management on seasonal variation in spontaneous lipolysis in bovine milk. J. Dairy Res. 53:529-538.

Degano, L., G. Contarini, O. Formichi, D. Ravera, and R. Giangiacomo. 2004. Introduction of AMS in Italian dairy herds. A new system for the evaluation of milk fat globule size as affected by automatic milking. Page 362 in Automatic milking. A better understanding. A. Meijering, H. Hogeveen, and C. J. A. M. de Koning, ed. Wageningen Academic Publishers, Wageningen, The Netherlands.

de Koning, K., B. A. Slaghuis, and Y. van der Vorst. 2004. Milk quality on farms with an automatic milking system. Pages 311-320 in Automatic milking. A better understanding. A. Meijering, H. Hogeveen, and C. J. A. M. de Koning, ed. Wageningen Academic Publishers, Wageningen, The Netherlands.

DePeters, E. J., N. E. Smith, and J. Acedo-Rico. 1985. Three or two times daily milking of older cows and first-lactation cows for entire lactations. J. Dairy Sci. 68:123-132.
Gisi, D. D., E. J. DePeters, and C. L. Pelissier. 1986. Three times daily milking in California dairy herds. J. Dairy Sci. 69:863-868.

Grummer, R. R. 1991. Effect of feed on the composition of milk fat. J. Dairy Sci. 74:3244-3257.

Hamann, J., F. Reinecke, H. Stahlhut-Klipp, and N. T. Grabowski. 2004. Effects of an automatic milking system (VMS ${ }^{\circledR}$ ) on free fatty acids (FFA) in different milk fractions. Pages 365-366 in Automatic milking. A better understanding. A. Meijering, H. Hogeveen, and C. J. A. M. de Koning, ed. Wageningen Academic Publishers, Wageningen, The Netherlands.

International Dairy Federation. 1981. IDF Standard 105. International Dairy Federation, Brussels, Belgium.

Jensen, R. G., A. M. Ferris, and C. J. Lammi-Keefe. 1991. The composition of milk fat. J. Dairy Sci. 74:3228-3243.

Klei, L. R., J. M. Lynch, D. M. Barbano, P. A. Oltenacu, A. J. Lednor, and D. K. Bandler. 1997. Influence of milking three times a day on milk quality. J. Dairy Sci. 80:427-436.

Klungel, G. H., B. A. Slaghuis, and H. Hogeveen. 2000. The effect of the introduction of automatic milking systems on milk quality. J. Dairy Sci. 83:1998-2003.

Lind, O., A. H. Ipema, C. de Koning, T. T. Mottram, and H.-J. Hermann. 2000. Automatic milking: Reality, challenges and opportunities. Pages 19-31 in Proc. Int. Symp. Robotic Milking, Lelystad, The Netherlands. H. Hogeveen and A. Meijering, ed. Wageningen Pers, Wageningen, The Netherlands.

Michalski, M. C., R. Cariou, F. Michel, and C. Garnier. 2002. Native vs. damaged milk fat globules: Membrane properties affect the viscoelasticity of milk gels. J. Dairy Sci. 85:2451-2461.

Michalski, M. C., J.-Y. Gassi, M.-H. Famelart, N. Leconte, B. Camier, F. Michel, and V. Briard. 2003. The size of native milk fat globules affects physico-chemical and sensory properties of Camembert cheese. Lait 83:131-143.

Ormiston, E. E., S. L. Spahr, R. W. Touchberry, and J. L. Albright. 1967. Effects of milking at unequal intervals for a complete lactation on milk yield and composition. J. Dairy Sci. 50:1597-1605.

Ouweltjes, W. 1998. The relationship between milk yield and milking interval in dairy cows. Livest. Prod. Sci. 56:193-201.

Palmquist, D. L., A. D. Beaulieu, and D. M. Barbano. 1993. Feed and animal factors influencing milk fat composition. J. Dairy Sci. 76:1753-1771.

Piccioli Cappelli, F., M. G. Maianti, G. Bertoni, E. Trevisi, and E. Brambilla. 1990. Sui fattori che modificano la composizione acidica e l'affioramento del grasso del latte: 1) La fase di lattazione. Sci. Tecn. Latt. Cas. 41:365-386.

Ronchi, B., U. Bernabucci, N. G. Lacetera, and A. Nardone. 1995. Milk fatty acid composition in cows exposed to hot environment. Pages 353-354 in Atti XI Congresso Nazionale Associazione Scientifica di Produzione Animale, Grado, Udine, Italy.

Santos, M. V., Y. Ma, Z. Caplan, and D. M. Barbano. 2003. Sensory threshold of off-flavors caused by proteolysis and lipolysis in milk. J. Dairy Sci. 86:1601-1607.

Shipe, W. F., G. F. Senyk, and K. B. Fountain. 1980. Modified copper soap solvent extraction method for measuring free fatty acids in milk. J. Dairy Sci. 63:193-198.

Slaghuis, B. A., K. Bos, O. de Jong, A. J. Tudos, M. C. te Giffel, and K. de Koning. 2004. Robotic milking and free fatty acids. Pages 341-347 in Automatic milking. A better understanding. A. Meijering, H. Hogeveen, and C. J. A. M. de Koning, ed. Wageningen Academic Publishers, Wageningen, The Netherlands.

Speroni, A., and G. Bertoni. 1984. L'affioramento del grasso del latte: Nuove proposte per la valutazione e l'interpretazione del fenomeno. Sci. Tecn. Latt. Cas. 35:97-108.

Svennersten-Sjaunja, K., I. Andersson, and H. Wiktorsson. 2004. The effect of milking interval on milk yield and composition. Page 515 in Automatic milking. A better understanding. A. Meijering, H. Hogeveen, and C. J. A. M. de Koning, ed. Wageningen Academic Publishers, Wageningen, The Netherlands.

Travers, M. T., and M. C. Barber. 1993. Isolation of a goat acetylCoA- carboxylase complementary DNA and effect of milking frequency on the expression of the acetyl-CoA- carboxylase and fatty acid synthase genes in goat mammary gland. Comp. Biochem. Physiol. B 105:123-128. 
Trevisi, E., M. Nazifi, G. Bertoni, and V. Cappa. 1992. Indagine preliminare sullinfluenza dei fattori stagionali nel determinismo di alcune caratteristiche del latte. Pages 513-519 in Atti Società Italiana di Buiatria (vol. XXIV), Bologna, Italy.

Walstra, P. 1969. Studies on milk fat dispersion. V. The mean distance between fat globules. Neth. Milk Dairy J. 23:245-249.

Walstra, P. 1994. Physical chemistry of milk fat globules. Pages 131178 in Advanced Dairy Chemistry. Volume 2: Lipids. P. F. Fox, ed. Chapman and Hall, London, UK.

Wauters, E., and E. Mathijs. 2004. The economic implications of automatic milking: a simulation analysis for Belgium, Denmark,
Germany and the Netherlands. Pages 68-74 in Automatic milking. A better understanding. A. Meijering, $\mathrm{H}$. Hogeveen, and $\mathrm{C}$. J. A. M. de Koning, ed. Wageningen Academic Publishers, Wageningen, The Netherlands.

Weiss, D., S. Helmreich, E. Möstl, A. Dzidic, and R. M. Bruckmaier. 2004. Coping capacity of dairy cows during the change from conventional to automatic milking. J. Anim. Sci. 82:563-570.

Wiking, L., L. Björk, and J. H. Nielsen. 2004. Impact of size distribution of milk fat globules on milk quality affected by pumping. Pages 348-356 in Automatic milking. A better understanding. A Meijering, H. Hogeveen, and C. J. A. M. de Koning, ed. Wageningen Academic Publishers, Wageningen, The Netherlands. 